\title{
Macrophages are involved in DNA degradation of apoptotic cells in murine thymus after administration of hydrocortisone
}

\author{
C Odaka ${ }^{\star, 1}$ and T Mizuochi ${ }^{1}$ \\ 1 Department of Bacterial and Blood Products, National Institute of Infectious \\ Diseases, Tokyo, 162-8640, Japan \\ * Corresponding author: C Odaka, Department of Bacterial and Blood Products, \\ National Institute of Infectious Diseases, 1-23-1, Toyama, Shinjuku-ku, Tokyo, \\ 162-8640, Japan. Tel: +81(3)5285-1111 ext. 2325; Fax: +81(3)5285-1150
}

Received 1.5.01; revised 16.7.01; accepted 8.8.01

Edited by $\mathrm{H}$ Ichijo

\begin{abstract}
In the present study, we undertook kinetic analyses of DNA degradation and acid DNase activity in murine thymus after administration of hydrocortisone. Hydrocortisone induced apoptosis in thymocytes, and a large number of cortical thymocytes became TUNEL (terminal deoxynucleotidyl transferase-mediated dUTP biotin nick end labelling)-positive (TUNEL ${ }^{+}$). $\mathrm{F} 4 / 80^{+}$macrophages infiltrated through the corticomedullay junction into the cortical region, and thereafter engulfed apoptotic cells in the cortex of thymus. The distribution of acid DNase-active cells appeared to be similar to that of $\mathrm{F} 4 / 8 \mathrm{O}^{+}$macrophages. Eighteen hours after the injection, although the foci of apoptotic cells were situated within massively distended $\mathrm{F} 4 / 80^{+}$macrophages, oligonucleosomal DNA fragments on an agarose gel were undetectable. Our results showed that macrophages were involved in the disappearance of oligonucleosomal DNA fragments in apoptotic thymocytes. Taken together, macrophages play a role in the hydrolysis of DNA in apoptotic cells upon their phagocytosis of the dead cells.

Cell Death and Differentiation (2002) 9, 104 - 112. DOI: 10.1038/sj/ cdd/4400941
\end{abstract}

Keywords: apoptosis; thymus; macrophages; DNA degradation

Abbreviations: $C A D$, caspase-activated DNase; ICAD, inhibitor of CAD; DFF, DNA fragmentation factor; DFF45, 45-kDa subunit of DFF; DFF40, 40-kDa subunit of DFF; CPAN, caspase-activated nuclease; DN, double negative; DP, double positive; SP, single positive; TdT, terminal deoxynucleotidyl transferase; TUNEL, terminal deoxynucleotidyl transferase-mediated dUTP biotin nick end labelling.

\section{Introduction}

Apoptosis is a cell death process that removes unwanted cells during mammalian development. ${ }^{1}$ One of the hallmarks of apoptosis is the degradation of nuclear DNA into nucleosomal units, which is demonstrated as a 'DNA ladder' by gel electrophoresis. ${ }^{2}$ These oligonucleosomal fragments of DNA in some apoptotic cells are derived from DNA fragments of $300 \mathrm{and} / \mathrm{or} 50 \mathrm{~kb}$ in length. 3,4

The endonuclease responsible for the cleavage of chromosomal DNA during apoptosis has been intensively investigated. From the results of early studies, a endonuclease that is activated in the presence of $\mathrm{Ca}^{2+}$ and $\mathrm{Mg}^{2+}$, has been proposed to be responsible for the internucleosomal cleavage of nuclear DNA during apoptosis. ${ }^{5}$ The $\mathrm{Ca}^{2+} / \mathrm{Mg}^{2+}$-dependent endonuclease is constitutively expressed in the nucleus isolated from various cells, and its optimum $\mathrm{pH}$ has been considered to be around 7-8. In contrast, some myeloid leukemia cells are shown to possess a $\mathrm{Ca}^{2+}$-independent and $\mathrm{Mg}^{2+}$-dependent endonuclease in their nuclei. ${ }^{6}$ Thus, the ion dependence of the nuclear DNase differs among various studies. Furthermore, several enzymes such as DNase I, ${ }^{7,8}$ DNase II, ${ }^{9,10}$ DNase $\gamma,{ }^{11} \mathrm{NUC} 18^{12}$ and cyclophilin ${ }^{13}$ have been proposed as candidates for the nuclease responsible for DNA cleavage during apoptosis, but the involvement of DNase I in the apoptotic DNA fragmentation was ruled out by characterization of it deficient cells. ${ }^{14}$

Recently, a DNase, designated as caspase-activated DNase (CAD), was found to be responsible for oligonucleosomal DNA degradation during apoptosis. It exists as a complex with its inhibitor (ICAD) in growing cells. Caspase-3, which is activated during the apoptotic process, cleaves ICAD, and CAD released from ICAD digests the chromosomal DNA. ${ }^{15,16}$ Human homologues of CAD and ICAD have been identified as DFF40 or CPAN, and DFF45, respectively. ${ }^{17-19} \mathrm{CAD}$ is also shown to be responsible for the large-scale degradation of chromosomal DNA. ${ }^{20}$ Although ICAD and CAD have previously been identified as cytoplasmic factors, ${ }^{15,16}$ recent study demonstrated that these molecules are nuclear proteins. ${ }^{21}$ In addition, it remains unclear whether the $\mathrm{Ca}^{2+} / \mathrm{Mg}^{2+}$-dependent or $\mathrm{Mg}^{2+}$-dependent endonuclease might be identical to CAD/DFF40/CPAN. Recently identified mitochondrial apoptosis-inducing factor (AIF) is shown to be able to cleave the chromatin of isolated nuclei into the fragments of $\sim 50 \mathrm{~kb},{ }^{22}$ and it is likely that at least a couple of DNases may be involved in the appearance of DNA fragmentation during apoptosis.

The preferential apoptosis of DP thymocyte subset by glucocorticoids, irradiation, or anti-CD3 antibody has been well documented in in vivo as well as in vitro systems. ${ }^{23-30}$ Recent studies, using the terminal deoxynucleotidyl transferase-mediated dUTP-biotin nick end labelling (TUNEL) method to examine the distribution of apoptotic thymocytes after administration of glucocorticoids or anti-CD3 antibody, ${ }^{31-33}$ have shown that the majority of immature thymocytes die in the cortical region of the thymus and 
that most of detectable apoptotic cells are localized within thymic macrophages. These studies indicate that thymic macrophages are the principal stromal cells responsible for phagocytosis of dying thymocytes and that the number of TUNEL $^{+}$thymocytes declines to the original basal level after apoptotic cells are phagocytosed by macrophages. We have previously investigated the fate of apoptotic cells after the engulfment by macrophage cell lines and found a rapid disappearance of DNA strand breaks in apoptotic cells, as assessed by TUNEL staining. Moreover, when the DNA of apoptotic cells engulfed by macrophages was analyzed by electrophoresis on an agarose gel, oligonucleosomal DNA fragments in apoptotic cells became undetectable. Based on these observations, we have proposed that DNase II-like acid nuclease in the lysosomes of macrophages is responsible for degradation of nucleosomal DNA fragments of apoptotic cells. ${ }^{34}$ Mcllory et al. ${ }^{35}$ also demonstrated DNA cleavage of apoptotic cells by macrophages in vivo and in vitro.

In this study, to extend our previous findings to an in vivo system, we undertook kinetic studies of DNA degradation in murine thymus after administration of hydrocortisone and found that macrophages were involved in the disappearance of oligonucleosomal DNA fragmentation. Furthermore, we examined histochemically the activity of acid DNase in the thymic sections, and the distribution of acid DNase-active cells in the thymus appeared to be similar to that of $\mathrm{F} 4 / 80^{+}$macrophages. These data of the experiments using murine thymus after administration of hydrocortisone support our previous proposal ${ }^{34}$ that acid DNase in macrophages plays a role in the hydrolysis of DNA in apoptotic cells upon their phagocytosis of the dead cells.

\section{Results}

\section{Injection of hydrocortisone into normal mice induces depletion of cortical CD4 ${ }^{+} \mathrm{CD}^{+}$ thymocytes}

It is well established that the exposure of thymocytes to glucocorticoids leads to depletion of $\mathrm{CD}^{+} \mathrm{CD}^{+}$(DP) thymocytes. $^{25,26}$ To confirm this, we injected hydrocortisone into 6-week-old C57BL/6 mice and examined total number of thymocytes and thymocyte subpopulations using fluorescent anti-CD4 and anti-CD8 antibodies. As shown in Figure 1A, a decrease in the total number of thymocytes was detectable after $12 \mathrm{~h}$ of hydrocortisone-injection. As expected from the previous report, ${ }^{26}$ at $24 \mathrm{~h}$ after the injection, the decrease was apparent and ranged from $75-83 \%$ of the values obtained for control mice. The cell surface marker analysis showed a decrease in the number of DP thymocytes following the administration of hydrocortisone (Figure 1B). We observed a significant decrease in the percentage of DP thymocytes (from 81 to $68 \%$ for $16 \mathrm{~h}$ post-injection and to $30 \%$ for $18 \mathrm{~h}$ post-injection). By $24 \mathrm{~h}$, hydrocortisone induced the depletion of nearly all DP thymocytes, resulting in a proportional increase in the percentage of SP thymocytes and of DN thymocytes, and most of residual thymocytes were SP and DN thymocyte populations.
A

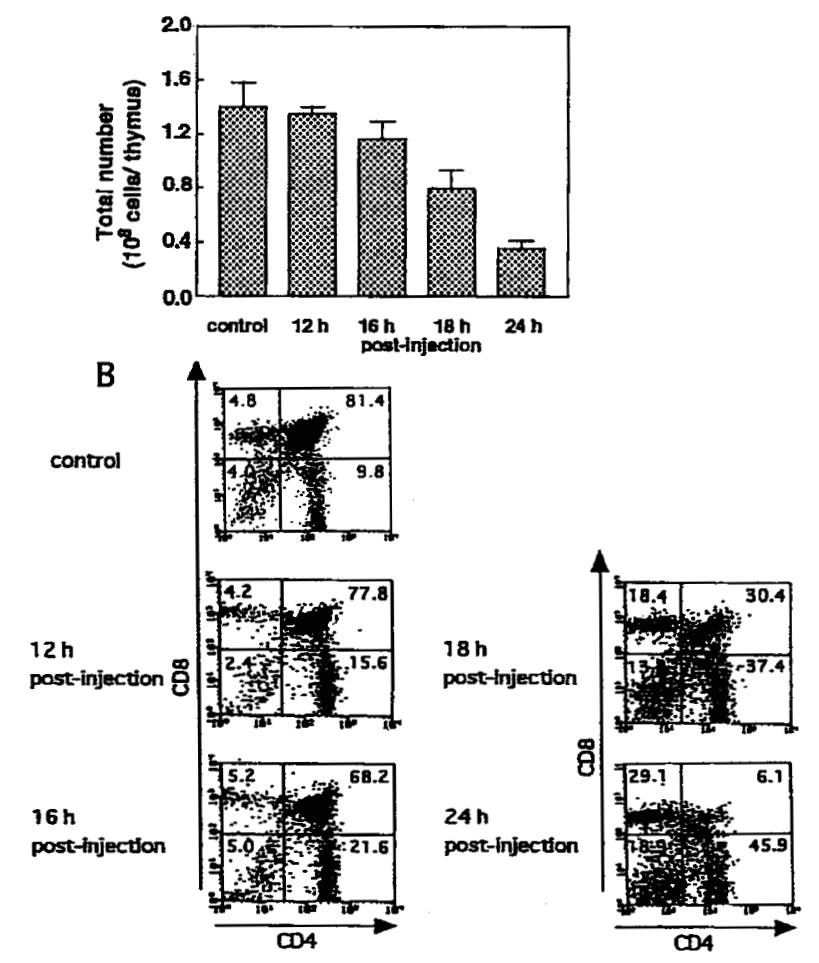

Figure 1 Injection of hydrocortisone into normal mice induces the depletion of $\mathrm{CD}^{+} \mathrm{CD}^{+}$thymocytes. Six-week-old C57BL/6 mice were injected i.p. with $125 \mathrm{mg} / \mathrm{kg}$ hydrocortisone sodium phosphate. (A) Reduction of thymocyte cell numbers after administration of hydrocortisone. After the indicated period, each thymus was removed and the cell number of thymocytes was counted. The data represents the mean \pm S.D. of total thymocyte numbers of four mice in each experiment. (B) Thymocyte subpopulations after administration of hydrocortisone. After each thymus was removed at the indicated period, thymocytes were stained with FITC-anti-CD4 and PE-anti-CD8 and analyzed using a FACScan. Numbers represent percentages in each quadrant. The data are representative of four mice in each experiment

\section{In situ detection of apoptotic cells and macrophages in the thymus after administration of hydrocortisone}

Apoptotic cells with DNA strand breaks in the thymus after in vivo injection of glucocorticoid can be visualised by TUNEL method. ${ }^{32,33}$ Next, we also used the method for detecting the cells that exhibit DNA cleavage in the thymus after administration of hydrocortisone. Additionally, we examined the distribution of macrophages in the thymus by staining with F4/80 antibody. ${ }^{36}$ In the thymus of normal mice, the cells with nuclear DNA breaks were rare but scattered in the cortex and to a lesser degree in the medulla. $\mathrm{F} 4 / 80^{+}$macrophages were dispersed throughout normal thymus (Figure 2a). Although the shrinkage of the cortex was not manifest until $12 \mathrm{~h}$ after the injection, cortical thymocytes showed extensive signs of apoptosis, as judged by DNA strand breaks as early as $12 \mathrm{~h}$ post-injection (Figure $2 \mathrm{~b}$ ). At this time, $\mathrm{F} 4 / 80^{+}$macrophages appeared in the thymus, principally in the medulla and the cortico-medullay region and in a lesser number in the cortex. These cells appeared to form a gradient, which was peaked in 


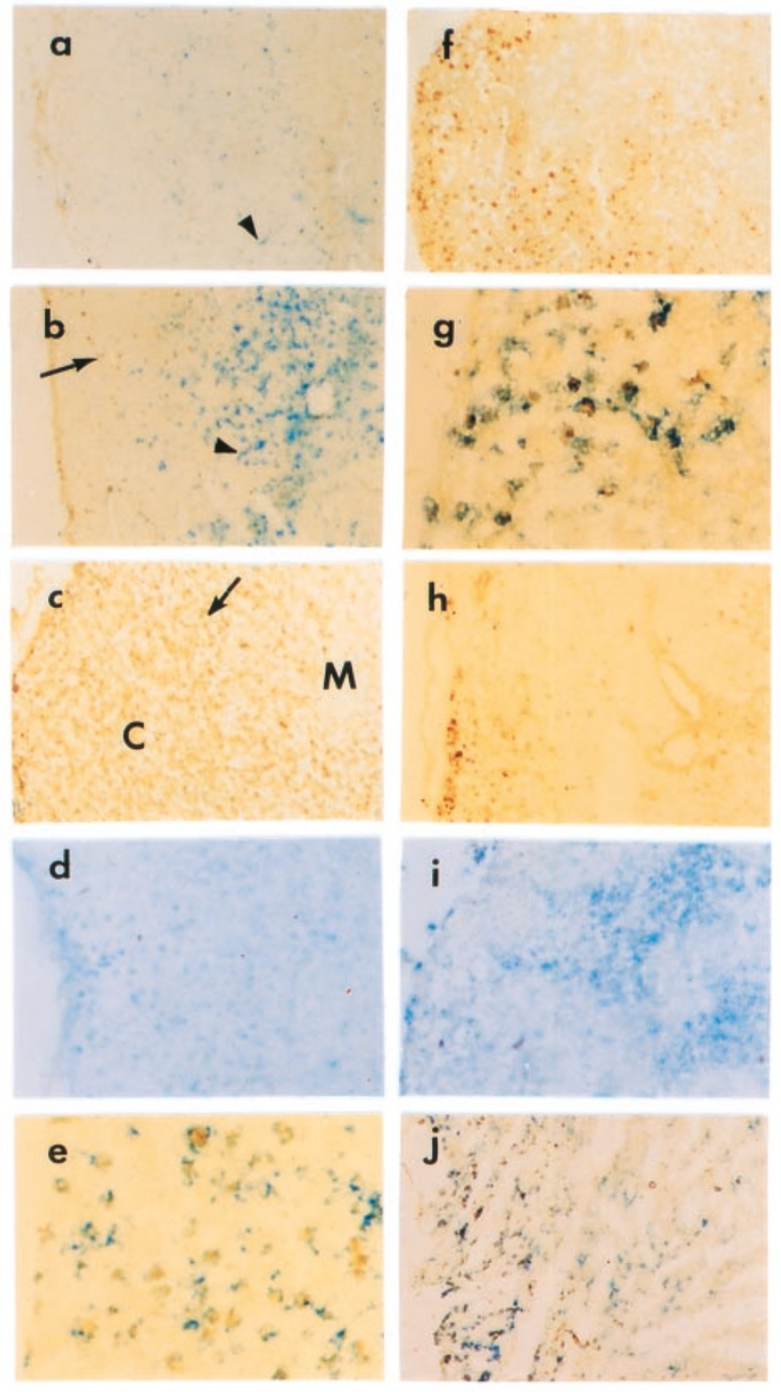

Figure 2 In situ detection of apoptotic cells and macrophages in murine thymus after administration of hydrocortisone. C57BL/6 mice were injected i.p. with $125 \mathrm{mg} / \mathrm{kg}$ hydrocortisone, and each thymus was removed at the indicated time. Cryostat sections of thymus were stained by TUNEL method $(\mathbf{c}, \mathbf{f}, \mathbf{h})$ o with F4/80 antibody (d, i). Sections were double-labelled with TUNEL and F4/ 80 antibody (a, b, e, g, j). Counterstaining was performed with Meyer's haematoxylin. (a) Thymus from control untreated mouse; (b) thymus from mouse at $12 \mathrm{~h}$ post-injection; $(\mathrm{c}-\mathrm{e})$ thymus from mouse at $16 \mathrm{~h}$ post-injection; $(\mathbf{f}, \mathbf{g})$ thymus from mouse at $18 \mathrm{~h}$ post-injection; $(\mathbf{h}-\mathbf{j})$ thymus from mouse at $24 \mathrm{~h}$ post-injection. Thymic cortex (C) and medulla (M) are indicated; Arrows and arrow heads indicate thymocytes expressing TUNEL ${ }^{+}$cells (brown) and $\mathrm{F} 4 / 80^{+}$macrophages (blue), respectively; Magnifications; (a-d, f, h) $\times 40$ (j) $\times 100,(\mathbf{e}, \mathbf{g}) \times 250$. These figures are representative of four mice for each experiment

the cortico-medullary junction (Figure 2b). Injection of hydrocortisone into mice induced a massive increase in the number of apoptotic cells in the thymus within $16 \mathrm{~h}$ (Figure 2c). Consistent with the previous study, ${ }^{32}$ a great number of TUNEL $^{+}$cells were scattered throughout cortical area, and some of the $\mathrm{TUNEL}^{+}$thymocytes were aggregated to form clusters. The staining with F4/80 antibody showed a number of enlarged macrophages dispersed throughout the cortical thymus (Figure 2d). Moreover, double stainings for nuclear
DNA breaks and macrophages revealed that most of the apoptotic cells in the cortex were situated within $\mathrm{F} 4 / 80^{+}$cells, suggesting that $\mathrm{TUNEL}^{+}$thymocytes were engulfed by macrophages (Figure 2e). This finding agrees with the previous study which reported that apoptotic cells are rapidly engulfed by macrophages and that most of the macrophages in the thymus are found to contain apoptotic bodies. ${ }^{32,33} \mathrm{At}$ $18 \mathrm{~h}$ after the injection, the number of the $\mathrm{TUNEL}^{+}$clusters further increased (Figure 2f). The foci of 5-10 TUNEL ${ }^{+}$ thymocytes were observed within $\mathrm{F} 4 / 80^{+}$macrophages, and nearly all TUNEL ${ }^{+}$thymocytes appeared to be engulfed by F4/ $80^{+}$macrophages (Figure $2 \mathrm{~g}$ ). The number of $\mathrm{TUNEL}^{+}$ thymocytes decreased drastically between 18 and $24 \mathrm{~h}$, and by $24 \mathrm{~h} \mathrm{TUNEL}^{+}$cells were localised only in the subcapsular area of the thymus (Figure $2 \mathrm{~h}$ ). A large number of enlarged $\mathrm{F} 4 / 80^{+}$macrophages could still be observed (Figure 2i). F4/ $80^{+}$macrophages that were localised in the subcapsular area engulfed TUNEL ${ }^{+}$cells, whereas TUNEL ${ }^{+}$thymocytes could be no longer detected within $\mathrm{F} 4 / 80^{+}$cells that were in the medullay area of the thymus (Figure 2j).

\section{In situ detection of acid DNase activity in the thymus after administration of hydrocortisone}

We have shown that DNase II-like acid nuclease in the lysosomes of macrophages is responsible for the degradation of DNA fragments in apoptotic cells. ${ }^{34}$ Since the histochemical lead nitrate method has been used to demonstrate an acid DNase activity in tissue sections, ${ }^{37,38}$ we considered it a useful method for identification of the morphological localisation of acid DNase activity and therefore used this method for the detection of acid DNase activity in the thymus after administration of hydrocortisone. The site of enzymatic activity has an appearance of dense brown precipitates. As shown in Figure 3Aa, in the thymus of normal mice, acid DNase activity was detectable in rare stellate cells. Injection of hydrocortisone induced a massive increase of acid DNaseactive cells in the thymus. At $12 \mathrm{~h}$ after hydrocortisone injection, an increase in the number of cells showing acid DNase activity was found and the enzyme was active mainly in the cells localised in the cortico-medullay junction of the thymus (Figure 3Ab). Acid DNase-active cells were scattered throughout the thymus within $16 \mathrm{~h}$ (Figure 3Ac). An intense acid DNase activity was detected throughout the thymus of $18 \mathrm{~h}$ post-injection (data not shown), and it could still be detected $24 \mathrm{~h}$ after the injection in the cells localised in the subcapsular area or in a number of cells of the medulla (Figure 3A,d).

Macrophages and polymorphonuclear cells contain acid DNase(s) in their lysosomes. ${ }^{39,40}$ We have also observed that DNA hydrolytic enzyme of macrophages is mainly localised in the lysosomes and that the acid DNase is sensitive to DNase II inhibitors such as iodoacetic acid or zinc ion. ${ }^{34,41,42}$ To determine whether acid DNase activity is associated with macrophages, serial sections of the thymus at $24 \mathrm{~h}$ after administration of hydrocortisone were stained with TUNEL followed by antibody F4/80 or histochemically for acid DNase activity. As observed in Figure 2i, a number of $\mathrm{F} 4 / 80^{+}$macrophages were detected in the subcapsular area or in the medullay area (Figure $3 \mathrm{Ba}$ ). On the other 
A

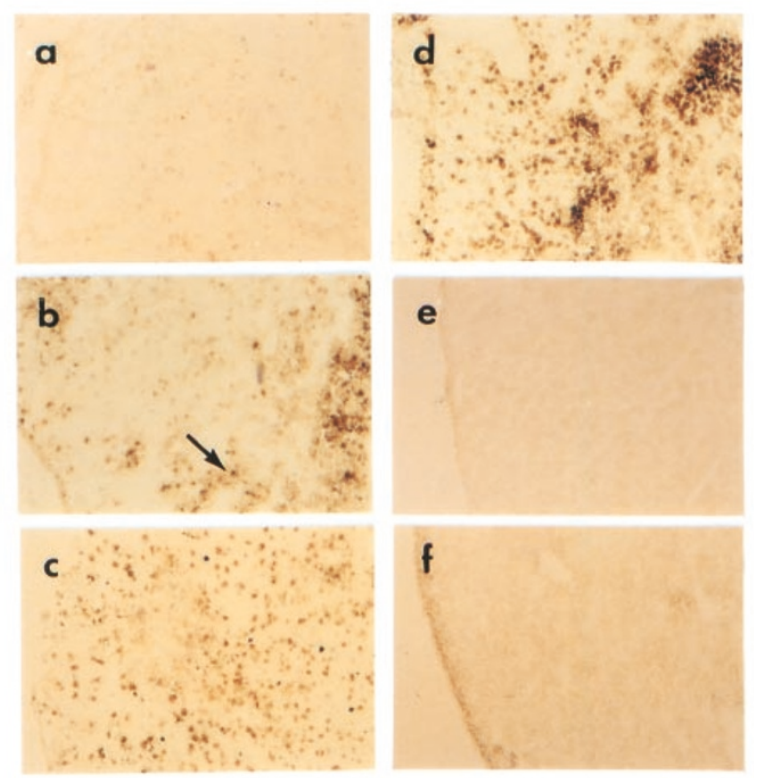

B
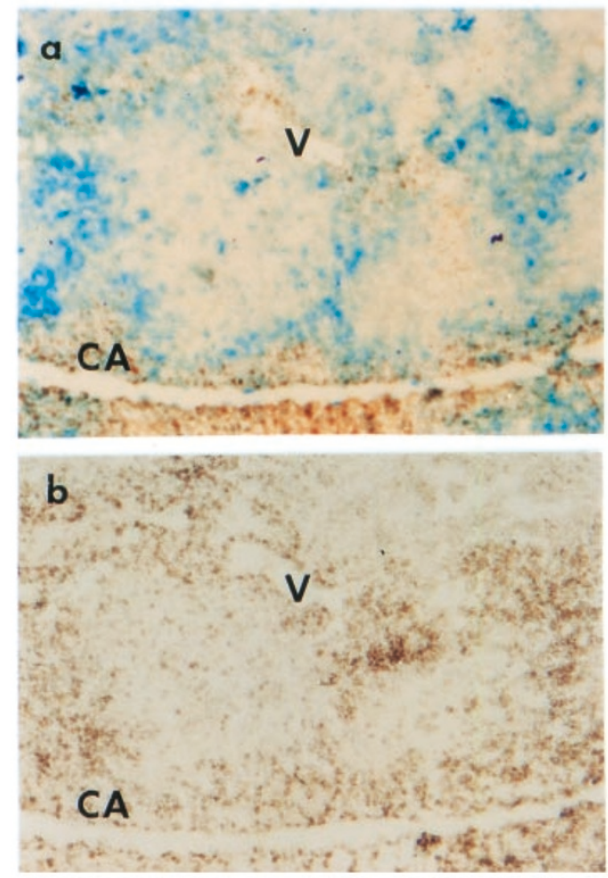

Figure 3 In situ detection of acid DNase in murine thymus after administration of hydrocortisone. (A) Acid DNase activity in the thymus after administration of hydrocortisone. C57BL/6 mice were injected i.p. with $125 \mathrm{mg} /$ $\mathrm{kg}$ hydrocortisone, and each thymus was removed at the indicated time. The detection of acid DNase was performed as described in Materials and Methods. (a) Thymus from control untreated mouse; (b) thymus from mouse at $12 \mathrm{~h}$ post-injection; (c) thymus from mouse at $16 \mathrm{~h}$ post-injection; $(\mathbf{d}-\mathbf{f})$ thymus from mouse at $24 \mathrm{~h}$ post-injection; (e) zinc ion was added into the reaction buffer; (f) iodoacetic acid was added into the reaction buffer. An arrow indicates the cell expressing acid nuclease activity (dark brown). Magnification, $\times 40$. (B) Serial frozen sections of the thymus at $24 \mathrm{~h}$ post-injection of hydrocortisone. C57BL/6 mice were injected i.p. with $125 \mathrm{mg} / \mathrm{kg}$ hydrocortisone, and each thymus was removed at $24 \mathrm{~h}$ post-injection. (a) Serial section was double-stained for apoptotic cells (brown) and for mAb F4/80 (blue), and then counterstained with Meyer's haematoxylin. (B) Serial section was stained hand, an intense acid DNase activity was mainly visible in the cells localised in the subcapsular area or in the cells of the medulla, some of which formed clusters in the site close to blood vessels (Figure 3Bb). Thus, the distribution pattern of the acid DNase-active cells was similar to that of $\mathrm{F} 4 / 80^{+}$ macrophages, and most of macrophages appeared to display an intense acid DNase activity. In addition, we added iodoacetic acid or $\mathrm{ZnSO}_{4}$ into the incubation buffer and examined their effects on acid DNase activity. The addition of iodoacetic acid or zinc ion into the incubation buffer resulted in the complete inhibition of acid DNase activity (Figure $3 A$ e and f).

\section{Macrophages are involved in the disappearance of oligonucleosomal DNA fragments in the thymus after administration of hydrocortisone}

Internucleosomal DNA cleavage is considered as a biological hallmark of apoptosis. ${ }^{2}$ We next examined DNA fragmentation on an agarose gel after the isolation of DNA from each thymus of mice 16 or $18 \mathrm{~h}$ after hydrocortisone-injection. As shown (Figure 2c), a significant increase in the number of TUNEL $^{+}$cells was detected at $16 \mathrm{~h}$ post-injection, and oligonucleosomal DNA fragmentation was detectable but not clearly (Figure 4, lanes 2,3). However, in one mouse from the three in this group, DNA fragmentation in the thymus was hardly detectable (Figure 4, lane 4). We examined DNA fragmentation at the earlier time point, and oligonucleosomal DNA fragmentation was hardly detectable (data not shown). Moreover, DNA fragmentation was no longer detectable in each thymus of three mice at $18 \mathrm{~h}$ after the injection (Figure 4, lanes 5-7), at which time almost $\mathrm{TUNEL}^{+}$thymocytes were phagocytosed by $\mathrm{F} 4 / 80^{+}$macrophages as shown in Figure $2 \mathrm{~g}$. Since the number of $\mathrm{TUNEL}^{+}$cells rapidly decreased within 16-24 $\mathrm{h}$ post-injection, it is likely that the DNA fragments of apoptotic cells might be digested within macrophages, resulting in the disappearance of oligonucleosomal DNA fragments when DNA was isolated from the thymuses of hydrocortisone-treated mice and analyzed by agarose gel electrophoresis.

To determine whether macrophages are involved in the disappearance of DNA fragmentation in agarose gel electrophoresis, each thymus taken from the mice $12 \mathrm{~h}$ post-injection of hydrocortisone was used for the following experiments. At this time point, although many $\mathrm{F} 4 / 80^{+}$ macrophages infiltrated into thymus, macrophages rarely engulfed apoptotic cells in the cortex, as observed in Figure $2 \mathrm{~b}$. When the cell suspension of one large lobe from each thymus was prepared and incubated at $37^{\circ} \mathrm{C}$ for $3 \mathrm{~h}$, the engulfment of apoptotic thymocytes into macrophages was observed (Figure 5Ac), but DNA fragmentation was clearly detected in the cells (Figure 5B, lanes 3-5). As for another large lobe from each thymus, each cell suspension was prepared and passed through a nylon wool column to

histochemically for acid DNase activity (dark brown). CA; thymic capsule, V; blood vessel in medulla. Magnification, $\times 150$. The data are representative of four mice in each experiment 


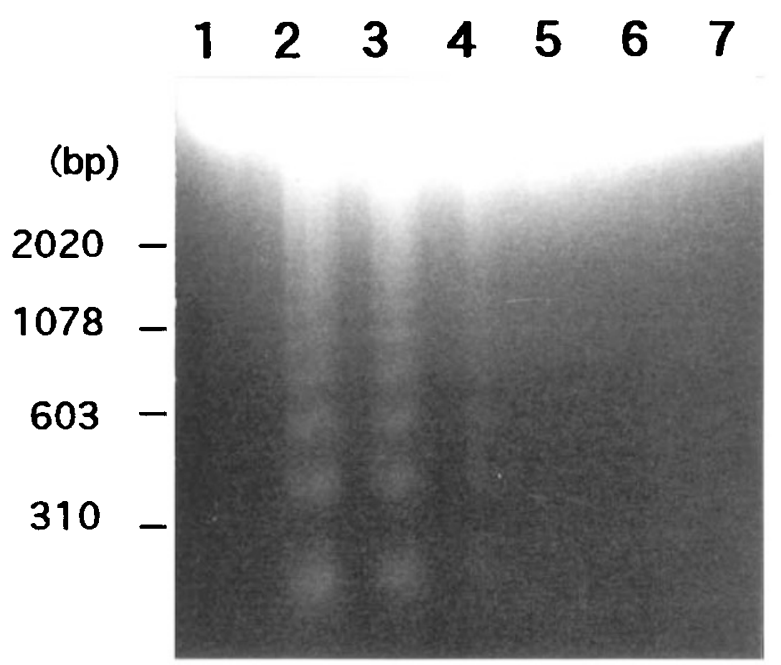

Figure 4 Detection of oligonucleosomal DNA fragments in the thymus after administration of hydrocortisone. C57BL/6 mice were injected i.p. with $125 \mathrm{mg} /$ $\mathrm{kg}$ hydrocortisone, and each thymus was removed at 16 or $18 \mathrm{~h}$ post-injection. DNA was isolated from the thymus as described as Materials and Methods and then subjected to $1.8 \%$ agarose gel electrophoresis. Lane 1 , thymus from control untreated mouse; lanes $2-4$, thymuses from mice of 16-h post injection; lanes $5-7$, thymuses from mice of 18 -h post injection. Each lane represents an individual mouse. The size of fragments shown in the left serves as molecular size markers (Hindlll digest of $\lambda$-phage DNA+Haell digest of $\varnothing \times 174)$

remove macrophages, and $\mathrm{F}_{4} / 80^{+}$cells were hardly detectable in the cell suspension passed through a nylon wool column, as determined by FACS analysis (data not shown). When these macrophage-depleted thymocytes were incubated at $37^{\circ} \mathrm{C}$ for $3 \mathrm{~h}$ (Figure 5Ad), DNA fragmentation was detected more obviously than in thymocytes together with a number of infiltrated macrophages (Figure 5B, lanes 8-10).

\section{Discussion}

We herein confirmed and extended earlier studies, in which the lethal effect of glucocorticoids on DP thymocytes is shown to be caused by induction of apoptosis.2,25,26 Injection of hydrocortisone into mice induced a massive increase in the number of $\mathrm{TUNEL}^{+}$cells in the thymus up to $16 \mathrm{~h}$. Double stainings by TUNEL method and with $\mathrm{F} 4 / 80$ antibody revealed that $\mathrm{TUNEL}^{+}$cells were rapidly engulfed by $\mathrm{F} 4 / 80^{+}$macrophages. After ingestion of apoptotic cells by macrophages, the number of $\mathrm{TUNEL}^{+}$thymocytes rapidly decreased between 16 and $24 \mathrm{~h}$. These findings are in agreement with previous studies. ${ }^{32,33}$

Noteworthy is the reproducible observation that as early as $12 \mathrm{~h}$ after administration of hydrocortisone, a number of $\mathrm{F} 4 / 80^{+}$macrophages appeared in the thymus, principally in the medulla and the cortico-medullay region. Although the shrinkage of the cortex was hardly detected until $12 \mathrm{~h}$ postinjection, cortical thymocytes began to become TUNELpositive. At $16 \mathrm{~h}$ of the injection, the number of $\mathrm{F} 4 / 80^{+}$cells in the cortex increased, suggesting the migration of macrophages from the medullay and cortico-medullay
A
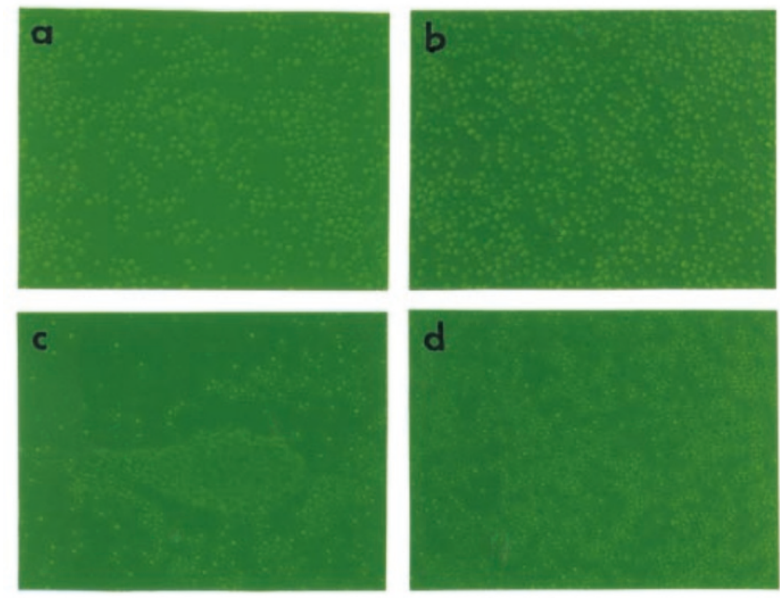

B

\begin{tabular}{crrrrrrrrrr} 
lane No. & 1 & 2 & 3 & 4 & 5 & 6 & 7 & 8 & 9 & 10 \\
mouse No. & 1 & 2 & 3 & 4 & 5 & 1 & 2 & 3 & 4 & 5 \\
\hline
\end{tabular}

(bp)

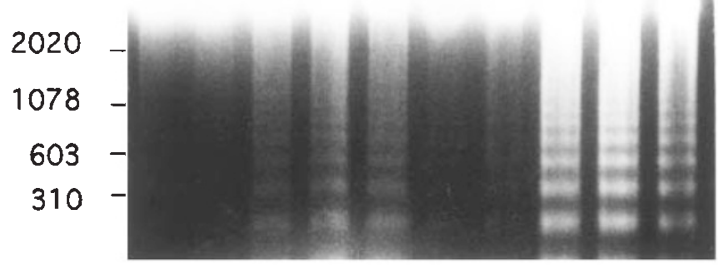

Figure 5 Appearance of DNA fragments in macrophage-depleted cell suspension from the thymus after administration of hydrocortisone. C57BL/6 mice were injected i. p. with saline (mice 1,2 ) or $125 \mathrm{mg} / \mathrm{kg}$ hydrocortisone (mice 3-5). At $12 \mathrm{~h}$ post-injection, each large lobe from thymus of mice was excised, and the cell suspension was prepared. Macrophage-depleted cell suspension from one large lobe of each thymus in individual mouse was prepared as nylon-nonadherent cells and then incubated at $37^{\circ} \mathrm{C}$ for $3 \mathrm{~h}$. Unfractionated cell suspension from another large lobe was also incubated at the same temperature as the macrophage-depleted cell suspension during the procedure of nylon wool columns, and then incubated at $37^{\circ} \mathrm{C}$ for $3 \mathrm{~h}$. (A) Engulfment of apoptotic thymocytes into macrophages; (a), unfractionated cell suspension from thymus (mouse 1); (b), macrophage-depleted cel suspension from thymus (mouse 1); (c), unfractionated cell suspension from thymus (mouse 3); (d), macrophage-depleted cel suspension from thymus (mouse 3). Magnification, $\times 100$. (B) DNA was isolated from the cells and then subjected to $1.8 \%$ agarose gel electrophoresis. Lanes 1,2 , cell suspension from each thymus with administration of saline (mice 1,2); lanes $3-5$, cell suspension from each thymus with administration of hydrocortisone (mice 3-5); lanes 6,7, macrophage-depleted cell suspension from each thymus with administration of saline (mice 1,2); lanes 8-10, macrophage-depleted cell suspension from each thymus with administration of hydrocortisone (mice $3-5)$. The size of fragments shown in the left serves as molecular size markers (Hindll digest of $\lambda$-phage DNA+Haell digest of $\varnothing \mathrm{X} 174)$

region to the cortical region. The estimated number of macrophages in murine thymus has been controversial due to the different methods used for collecting them. According to Zepp et al., ${ }^{43}$ who used bovine serum albumin (BSA) gradients, $1.5-3.5 \%$ of all thymic cells are low-density adherent cells including macrophages and dendritic cells. ${ }^{43}$ In the previous studies on the ontogeny of rat thymus, the cortico-medullary region has been regarded as the 
entrance site of blood monocytes. ${ }^{44,45}$ This increase of F4/ $80^{+}$cells in the thymus is presumably due to the arrival of migrated macrophages through vessels, rather than in situ proliferation of pre-existent macrophages. These findings imply that cortical thymocytes undergoing apoptosis may release a macrophage-chemoattractive factor within $12 \mathrm{~h}$ post-injection. It would be of interest to elucidate the molecular mechanism(s) by which circulating macrophages are attracted to the cortical region of the thymus.

In this study, we examined histochemically the activity of acid DNase in the thymic sections, since the histochemical method is convenient for detecting the site of the nuclease activity. In the thymus of normal mice, a weak acid DNase activity was observed in some of the scattered cells of normal thymus. Injection of hydrocortisone into mice induced a massive increase in the number of acid DNase-active cells in the thymus, and our results confirmed four decades old observations by two groups. ${ }^{46-49}$ Douglas' group has reported that total body $\mathrm{x}$-irradiation causes an increase in the activity of acid DNase in rat spleen. ${ }^{46,47}$ Additionally, they found that the activity is peaked 24-48 $\mathrm{h}$ post-irradiation at which time all the lymphocytes of spleen were already destroyed. Hempelmann's group also demonstrated that the activity of acid DNase increases markedly in spleen and thymus during the first 3 days after exposure of ionizing radiation or cortisone. ${ }^{48,49}$ They suggested that the radiation-sensitive lymphocytes contain little acid DNase activity and that radiation-resistant cells in the spleen or the thymus contribute to the increase of acid DNase activity. ${ }^{49}$ In our observations, at $24 \mathrm{~h}$ after the injection, although the number of $\mathrm{TUNEL}^{+}$apoptotic thymocytes drastically decreased and the thymus was almost entirely composed of medullay tissue, the duration of intense acid DNase activity could still be detected. In addition, the histological distribution of acid DNase activity was similar to that of F4/ $80^{+}$macrophages in the thymus of hydrocortisone-treated mice. These results suggest that acid DNase is not involved in thymocyte apoptosis itself. If the enzyme had been involved in the execution of apoptosis, we could have hardly detected acid DNase activity at $24 \mathrm{~h}$ post-injection. We have reported that an acid DNase in lysosomes of macrophages which is responsible for DNA degradation of apoptotic cells is similar to DNase II with respect to its molecular weight, optimal $\mathrm{pH}$ and sensitivity to DNase II inhibitors. ${ }^{34}$ The in situ activity of acid DNase was inhibited by the presence of iodoacetic acid or zinc ion, suggesting that the acid DNase possesses the character similar to that of DNase II in terms of the sensitivity to DNase II inhibitors. Although it remains unclear whether the acid DNase detected in the thymuses of hydrocortisone-injected mice is identical to DNase II, this issue, for instance, could be explored by an inhibition assay of acid DNase activity by anti-DNase II antibody in the histochemical method.

Glucocorticoid-induced apoptosis in thymocytes has been exclusively studied in cell culture systems and the oligonucleosomal fragmentation of genomic DNA is apparently detectable during the apoptosis. ${ }^{2}$ In our study, a large number of apoptotic cells were found with a maximum at $16 \mathrm{~h}$ post-injection as assessed by TUNEL staining.
However, although DNA fragmentation was detected when DNA was isolated from each thymus at this time point, the amounts of DNA fragments on an agarose gel were smaller than we expected. At $18 \mathrm{~h}$ after the injection, nucleosomal DNA fragments were no longer detectable in each thymus of hydrocortisone-treated mice. Nakamura et al. ${ }^{50}$ have reported that apoptosis in the thymuses of hydrocortisoneinjected mice occurs without DNA fragmentation. However, they also observed $\mathrm{TUNEL}^{+}$thymocytes, all of which are phagocytosed by $\mathrm{F} 4 / 80^{+}$macrophages. They therefore proposed that apoptotic thymocytes become $\mathrm{TUNEL}^{+}$only after being engulfed by macrophages. This seems to conflict, in part, with our present results, and two differences in the experimental system might account for this discrepancy: (1) we injected with $125 \mathrm{mg} / \mathrm{kg}$ of hydrocortisone into each mouse, whereas the dose of the drug by Nakamura et al. ${ }^{50}$ was $250 \mathrm{mg} / \mathrm{kg}$ and (2) we traced up to $24 \mathrm{~h}$, whereas they removed thymus at 2 or $4 \mathrm{~h}$ after the injection. Rather, we favour a hypothesis that a disappearance of oligonucleosomal DNA ladder formation in apoptotic thymocytes occurs upon the engulfment by macrophages. As early as $12 \mathrm{~h}$ after administration of hydrocortisone, nearly all apoptotic cells were not yet engulfed by $\mathrm{F} 4 / 80^{+}$ macrophages. When each thymus was removed at $12 \mathrm{~h}$ post-injection and each cell suspension was incubated at $37^{\circ} \mathrm{C}$ for $\sim 4 \mathrm{~h}$, DNA fragmentation on an agarose gel was detectable. Furthermore, when the cell suspension was depleted of the infiltrated macrophages, DNA fragmentation was detected more apparently than in cell suspension containing a number of macrophages. This finding implies that macrophages may be involved in the disappearance of DNA fragmentation. Since we found that a number of acid DNase-active cells were still distributed in the thymus even at $24 \mathrm{~h}$ post-injection and that the histological localisation of acid DNase-active cells appeared to be similar to that of F4/ $80^{+}$macrophages, it is plausible that acid DNase, which is presumably resides in macrophages, may be responsible for the degradation of oligonucleosomal DNA fragments in apoptotic cells. Therefore, the oligonucleosomal fragments of genomic DNA may be undetectable in glucocorticoidinduced thymocyte cell death in vivo.

In Caenorhabditis elegans, programmed cell death normally occurs in the mutants that lack the activity of nuc-1-encoded acid nuclease although the nucleus remains intact after phagocytosis. ${ }^{51,52}$ This indicates that the acid nuclease functions in late event after phagocytosis of dead cells. We have speculated that nuc-1 may encode a nuclease similar to DNase $1 .^{34}$ Indeed, Wu et al. ${ }^{53}$ demonstrated that the gene nuc-1 is a homologue of mammalian DNase II. Furthermore, they indicated that mutations of nuc-1 block the conversions of TUNELreactive DNA to a subsequent TUNEL-unreactive state. On the basis of our previous ${ }^{34}$ and present results, we propose a model of DNA degradation of mammalian apoptotic cells (Figure 6). Upon induction of apoptosis, ICAD (DFF45) is cleaved by caspase-3 and dissociated from CAD (DFF40/CPAN), resulting in the induction of CAD (DFF40/CPAN) nuclease activity. Since the DNA of nucleosomes is tightly complexed with the core histones and therefore protected from the cleavage by the nucle- 


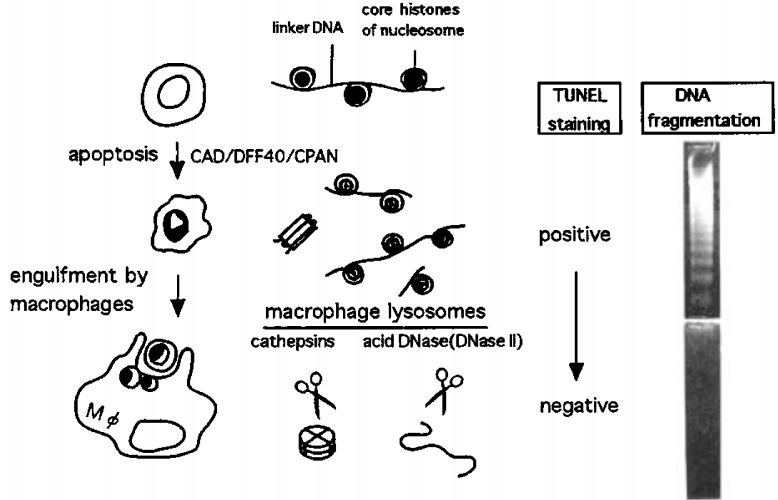

Figure 6 A model of DNA degradation of mammalian apoptotic cells

ase ${ }^{54}$ genomic DNA is cleaved at most accessible internucleosomal linker region, resulting that the DNA fragments yield discrete multiples of a $180 \mathrm{bp}$ subunit which is detected as a 'DNA ladder' on a gel. Once cells undergo apoptosis, they are recognised and engulfed by macrophages via a number of membrane receptors. After rapid engulfment by phagocytic macrophages, DNase II-like acid nuclease and cathepsins in macrophage lysosomes are responsible for the degradation of nucleosomes in apoptotic cells. Consequently, DNA strand breaks in apoptotic cells are disappeared, as assessed by TUNEL staining. In addition, nucleosomal DNA fragments in apoptotic cells are degraded into smaller random-sized fragments, thereby DNA ladder is no longer detectable as analyzed by electrophoresis on a gel.

\section{Material and Methods}

\section{Mice}

Six-week-old C57BL/6 female mice were obtained from Clea Japan Inc (Tokyo, Japan). Mice were injected i.p. with $125 \mathrm{mg} / \mathrm{kg}$ hydrocortisone sodium phosphate (Sigma, St. Louis, MO, USA) or with saline. At the indicated times, mice were sacrificed, and freshly isolated thymuses were immersed in OCT compound (Miles, Naperville, IL, USA). They were then rapidly frozen on dry ice and sectioned at $5 \mu \mathrm{m}$. Alternatively, thymus lobes were excised and a cell suspension was prepared from each lobe of individual mouse.

\section{Fluorescent marker analysis}

Thymocytes from each thymus were counted, and then stained with fluorescein isothiocyanate (FITC)-conjugated anti-CD4 (GK1.5 PharMingen, San Diego, CA, USA) and phycoerythrin (PE)-conjugated anti-CD8 (53-6.72; PharMingen). The staining was assessed by flow cytometry using a FACScan (Becton Dickinson, Mountain View, CA, USA). Dead cells were gated using propidium iodide (Sigma), and viable cells were analyzed for each thymus.

\section{In situ detection of DNA cleavage by TUNEL}

Frozen sections were air-dried and fixed in acetone. After incubation in $0.3 \% \mathrm{H}_{2} \mathrm{O}_{2}$ for $30 \mathrm{~min}$, the sections were incubated for $60 \mathrm{~min}$ at $37^{\circ} \mathrm{C}$ in a reaction buffer consisting of $100 \mathrm{mM}$ sodium cacodylate ( $\mathrm{pH} 7.2), 1 \mathrm{mM} \mathrm{CoCl}, 10 \mathrm{nM}$ biotin-16-dUTP (Boerhinger Mannheim Biochemicals, Mannheim, Germany), and 100 units/ml terminal deoxynucleotidyl transferase (TdT) (Takara Biochemicals, Shiga, Japan), followed by incubation with avidinbiotin-peroxidase complexes using the Vecstain-ABC kit (Vector, Burlingame, CA, USA) for $30 \mathrm{~min}$. The sections were washed and then incubated with a mixture of $0.06 \% 3-3^{\prime}$-diaminobenzidine tetrahydrochiloride (DAB, Sigma) and $0.03 \% \mathrm{H}_{2} \mathrm{O}_{2}$ in $0.05 \mathrm{M}$ Tris$\mathrm{HCl}(\mathrm{pH} 7.5)$. Counterstaining was performed with Meyer's haematoxylin. Microscopic observations were carried out by using Microflex UFX-II (Nikon Co. Ltd., Tokyo, Japan).

\section{Immunohistochemisty}

Frozen thymus sections were air-dried, fixed in acetone, and dehydrated in PBS. The sections were pre-incubated with PBS containing $5 \%$ normal goat serum, and incubated sequentially with a anti-macrophage antibody, $F 4 / 80^{36}$ (rat $\operatorname{lgG}_{2 b} \mathrm{mAb}$, Biomedicals AG., Augst, Switzerland) followed by the incubation with goat ant-rat IgG antibody conjugated with alkaline phosphate (Cappel, West Chester, PA, USA), and then incubated for $20 \mathrm{~min}$ at room temperature using the Alkaline Phosphate Substrate kit (Vector) to colour the reaction product blue. In some experiments, after the staining by TUNEL labelling, the sections were incubated first with $\mathrm{F} 4 / 80$, and second with goat ant-rat IgG antibody conjugated with alkaline phosphate. The sections were then developed with alkaline phosphate substrate. Counterstaining was performed with Meyer's haematoxylin.

\section{In situ detection of acid DNase activity}

Histochemical detection of acid DNase activity was performed according to the procedure described by Aronson et al. ${ }^{37}$ with slight modifications by Vorbrodt. ${ }^{38}$ Frozen thymus sections were air-dried and then incubated for $8 \mathrm{~h}$ at $37^{\circ} \mathrm{C}$ in a reaction buffer containing $0.05 \mathrm{M}$ sodium acetate $(\mathrm{pH} 5.2), 1 \mathrm{mM} \mathrm{Pb}\left(\mathrm{NO}_{3}\right)_{2}, 0.4 \mathrm{mg} / \mathrm{ml}$ herring sperm powder DNA (Sigma), and $0.1 \mathrm{mg} / \mathrm{ml}$ wheat germ acid phosphate (Sigma). Where indicated, iodoacetic acid or $\mathrm{ZnSO}_{4}$ was added into the reaction buffer at a concentration of $1 \mathrm{mM}$ or $2 \mathrm{mM}$, respectively. At the end of the incubation, the sections were rinsed with distilled water, and developed with $0.1 \%$ yellow aqueous solution of $\left(\mathrm{NH}_{4}\right)_{2} \mathrm{~S}$. After the sections were washed with distilled water, they were fixed for $2 \mathrm{~min}$ in a solution of $3.7 \%$ formaldehyde and mounted.

\section{Cell preparations and cell culture}

Each lobe from thymus was excised, and the cell suspension was prepared in RPMI 1640 medium (Grand Island, NY, USA) supplemented with $10 \%$ FCS, $5 \times 10^{-5} \mathrm{M}$ 2-ME, $1 \mathrm{mM}$ sodium pyruvate, $2 \mathrm{mM}$ L-glutamine, 100 units $/ \mathrm{ml}$ penicillin and $100 \mu \mathrm{g} / \mathrm{ml}$ streptomycin. The cell suspension of one large lobe from each thymus was loaded in a nylon wool column and incubated in a $37^{\circ} \mathrm{C}, 5 \% \mathrm{CO}_{2}$ humidified incubator for $45 \mathrm{~min}$. The macrophagedepleted cells were collected and resuspended in the above medium. Each cell suspension prepared from another large lobe was incubated at the same temperature as the macrophagedepleted cell suspension during the procedure of nylon wool columns. These cells were seeded into 24 -well culture plates at a density of $5 \times 10^{6}$ cells/well and then incubated at $37^{\circ} \mathrm{C}$ for $3 \mathrm{~h}$. 


\section{Isolation of DNA and detection of DNA fragmentation}

The cleavage of DNA into nucleosomal fragments was assessed by fractionating DNA on an agarose gel as described previously. ${ }^{29}$ In brief, thymocytes were lysed in the buffer containing $10 \mathrm{mM}$ Tris- $\mathrm{HCl}$ (pH 8.0), 0.5\% N-lauroylsarcosine and 0.1 M EDTA, and treated with $100 \mu \mathrm{g} / \mathrm{ml}$ proteinase $\mathrm{K}$ and $50 \mu \mathrm{g} / \mathrm{ml}$ RNase A. The DNA was extracted by phenol/chloroform and precipitated in isopropyl alcohol containing $0.5 \mathrm{M} \mathrm{NaCl}$. After the sample was centrifuged, the pellet was washed with $70 \%$ ethanol and allowed to dry at room temperature. The DNA was resuspended in TE buffer $(10 \mathrm{mM}$ Tris- $\mathrm{HCl}(\mathrm{pH} \mathrm{8.0)}$, $1 \mathrm{mM}$ EDTA), and then DNA equivalent to $2.5 \times 10^{5}$ cells was fractionated by electrophoresis on a $1.8 \%$ agarose gel containing ethidium bromide. The gels were photographed using UV transilluminator.

\section{References}

1. Wyllie AH, Kerr JFR and Currie AR (1980) Cell death: the significance of apoptosis. Int. Rev. Cytol. 68: 251-306

2. Wyllie AH (1980) Glucocorticoid-induced thymocyte apoptosis is associated with endogenous endonuclease activation. Nature 284: 555-556

3. Brown DG, Sun XM and Cohen GM (1993) Dexamethasone-induced apoptosis involves cleavage of DNA to large fragments prior to internucleosomal fragmentation. J. Biol. Chem. 268: 3037-3039

4. Oberharmmer F, Wilson JW, Dive C, Morris ID, Hickman JA, Wakolong AE, Walter PR and Sikorska M (1993) Apoptotic death in epithelial cells: Cleavage of DNA to 300 and/or $40 \mathrm{~kb}$ fragments prior to or in the absence of internucleosomal fragmentation. EMBO J. 12: 3679-3684

5. Cohen JJ and Duke RC (1984) Glucocorticoid activation of a calcium-dependent endonuclease in thymocyte nuclei leads to cell death. J. Immunol. 132: 38-42

6. Kawabata H, Anzaki N, Masutani N, Hirama T, Yoshida Y and Okuma M (1993) Detection of $\mathrm{Mg}^{2+}$-dependent endonuclease activity in myeloid leukemia cell nuclei capable of producing internucleosomal DNA cleavage. Biochem. Biophys. Res. Commun. 191: 247-254

7. Ucker DS, Obermiller PS, Eckhart W, Apgar JR, Berger NA and Meyers J (1992) Genome digestion is a dispensable consequence of physiological cell death mediated by cytotoxic T lymphocytes. Mol. Cell. Biol. 12: 3060-3069

8. Peitsch MC, Polzar B, Stephan H, Crompton T, MacDonald HR, Mannherz HG and Tschopp J (1993) Characterization of the endogeneous deoxyribonuclease involved in nuclear DNA degradation during apoptosis (programmed cell death). EMBO J. 12: $371-377$

9. Barry MA and Eastmann A (1993) Idetification of deoxyribonuclease II as an endonuclease involved in apoptosis. Arch. Biochem. Biophys. 300: 440-450

10. Torriglia A, Chaudun E, Chany-Fournier F, Jesnny JC, Courois $Y$ and Counis MF (1995) Involvement of DNase II in nuclear degradation during lens cell differentiation. J. Biol. Chem. 270: 28579-28585

11. Shiokawa D, Ohyama H, Yamada T, Takahashi K and Tanuma S (1994) Identification of an endonuclease responsible for apoptosis in rat thymocytes. Eur J Biochem. 226: 23-30

12. Gaido ML and CidlowskiJA (1991) Idetification, purification and characterization of a calcium-dependent endonuclease (NUC18) from apoptotic rat thymocytes. NUC 18 is not histone H2B. J. Biol. Chem. 266: 18580-18586

13. Montague JW, Gaido ML, Frye C and Cidlowski JA (1994) A calcium-dependent nuclease from apoptotic rat thymocytes is homologous with cyclophilin. Recombinant cyclophilins A, B, and C have nuclease activity. J. Biol. Chem. 269: $18877-18880$

14. Napirei M, Karsunky H, Zevnik B, Stephan H, Mannherz HG and Moroy T (2000) Features of systemic lupus erythematosus in DNase1-deficient mice. Nat. Genet. 25: 177-181

15. Enari M, Sakahira H, Yokoyama H, Okawa K, Iwamatsu A and Nagata S (1998) A caspase-activated DNase that degrades DNA during apoptosis, and its inhibitor ICAD. Nature 391: 43-50

16. Sakahira $H$, Enari $M$ and Nagata $S$ (1998) Cleavage of CAD inhibitor in CAD activation and DNA degradation during apoptosis. Nature 391: $96-99$
17. Liu X, Zou H, Slaughter $C$ and Wang X (1997) DFF, a heterodimeric protein that functions downstream of caspase-3 to trigger. DNA fragmentation during apoptosis. Cell 89: 175-184

18. Halenbeck R, MacDonald H, Roulston A, Chen TT, Controy L and Williams LT (1998) CPAN, a human nuclease regulated by the caspase-sensetive inhibitor DFF 45. Curr. Biol. 8: $537-540$

19. Liu X, Li P, Widlak P, Zou H, Luo X, Garrard WT and Wang X (1998) The 40-kDa subunit of DNA fragmentation factor induces DNA fragmentation and chromatin condensation during apoptosis. Proc. Natl. Acad. Sci. U S A 95: 8461-8466

20. Sakahira H, Enari M, Ohsawa Y, Uchiyama Y and Nagata S (1999) Apoptotic nuclear morphological change without DNA fragmentation. Curr. Biol. 20: 543546

21. Samejima K and Earnshaw WC (1998) ICAD/DFF regulator of apoptotic nuclease is nuclear. Exp. Cell. Res. 243: 453-459

22. Susin SA, Lorenzo HK, Zamzami N, Marzo I, Snow BE, Brothers GM, Mangion J, Jacotot E, Costantini P, Loeffer M, Larochette N, Goodlett DR, Aebersold R, Siderovski DP, Penninger JM and Kroemer G (1999) Molecular characterization of mitochondorial apoptosis-inducing factor. Nature 397: 441-446

23. Ohyama $H$ and Yamada $T$ (1985) Radiation-induced formation of apoptotic bodies in rat thymus. Radiat. Res. 101: 123-130

24. Mori N, Nishikawa R, Okumoto M, Nishikawa K, Imai S, Narita N, Takamori Y and Yagasaki O (1991) Strain difference in the susceptibility of thymocytes to radiation-induced apoptosis: in vitro study. J. Radiat. Res. (Tokyo) 32: 277-285

25. van Ewijk W, van Soest PL and van den Engh GJ (1981) Fluorescence analysis and anatomic distribution of mouse T lymphocyte subsets defined by monoclonal antibodies to the antigens Thy-1, Lyt-1, Lyt-2, and T-200. J. Immunol. 127: 2594-2604

26. Screpanti I, Morrone S, Meco D, Santoni A, Gulino A, Paolini R, Crisanti A, Mathieson BJ and Frati L (1989) Steroid sensitivity of thymocyte subpopulations during intrathymic differentiation. Effects of 17 beta-estradiol and dexamethasone on subsets expressing T cell antigen receptor or IL-2 receptor. J. Immunol. 142: $3378-3383$

27. Smith CA, Williams GT, Kingston R, Jenkinson EJ and Owen JJ (1989) Antibodies to CD3/T-cell receptor complex induce death by apoptosis in immature T cells in thymic cultures. Nature 337: 181-184

28. McConkey DJ, Hartzell P, Amador-Perez JF, Orrenius S and Jondal M (1989) Calcium-dependent killing of immature thymocytes by stimulation via the CD3/T cell receptor complex. J. Immunol. 143: 1801-1806

29. Tadakuma T, Kizaki H, Odaka C, Kubota R, Ishimura Y, Yagita Hand Okumura K (1990) $C D 4^{+} \mathrm{CD}^{+}$thymocytes are susceptible to DNA fragmentation induced by phorbol ester, calcium ionophore and anti-CD3 antibody. Eur. J. Immunol. 20: $779-784$

30. Shi YF, Bissonnette RP, Parfrey N, Szalay M, Kubo RT and Green DR (1991) In vivo administration of monoclonal antibodies to the CD3/T cell receptor complex induces cell death (apoptosis) in immature thymocytes. J. Immunol. 146: 3340 3346

31. Gavrieli Y, Sherman $Y$ and Ben-Sasson SA (1992) Identification of programmed cell death in situ via specific labelling of nuclear DNA fragmentation. J. Cell. Biol. 119: 493-501

32. Fehsel K, Kroncke KD, Kolb H and Kolb-Bachofen V (1994) In situ nicktranslation detects focal apoptosis in thymuses of glucocorticoid- and lipopolysaccharide-treated mice. J. Histochem. Cytochem. 42: 613-619

33. Surh CD and Sprent J (1994) T-cell apoptosis detected in situ during positive and negative selection in the thymus. Nature 372: 100-103

34. Odaka C and Muzuochi T (1999) Role of macrophage lysosomal enzymes in the degradation of nucleosomes of apoptotic cells. J. Immunol. 164: 5346-5352

35. Mcllroy D, Tanaka M, Sakahira H, Fukuyama H, Suzuki M, Yamamura K, Ohsawa Y, Uchiyama Y and Nagata S (2000) An auxiliary mode of apoptotic DNA fragmentation provided by phagocytes. Genes. Dev. 14: 549-558

36. Austyn JM and Gordon S (1981) F4/80, a monoclonal antibody directed specifically against the mouse macrophage. Eur. J. Immunol. 11: 805-815

37. Aronson J, Hempelmann LH and Okada S (1958) Preliminary studies on the histological demonstration of deoxyribonuclease II by adaptation of the Gomori acid phosphatase method. J. Hischem. Cytochem. 6: 255-259

38. Vorbrodt A (1961) Histochemical studies on the intracellular localization of acid deoxyribonuclease. J. Histochem. Cytochem. 9: 647-655

39. de Duve CB, Pressman C, Gianetto R, Wattiaux R and Applemans F (1955) Tissue Fractionation studies 6 . Intracellular distribution patterns of enzymes in rat-liver tissue. Biochem. J. 60: 604-609 
40. Bernardi G (1971) Spleen acid doexyribonuclease. In: Boyer PD (ed) The Enzymes, Vol. 4. Academic Press, New York: pp. 271-323

41. Dulaney JT and Touster O (1972) Isolation of deoxyribonuclease II of rat liver lysosomes. J. Biol. Chem. 247: 1424-1432

42. Oshima RG and Price PA (1973) Alkylation of an essential histidine residue in porcine spleen deoxyribonuclease. J. Biol. Chem. 248: 7522-7526

43. Zepp F, Schulte-Wissermann H and Mannhardt W (1984) Macrophage subpopulations regulate intrathymic T-cell development. I: la-positive macrophages augment thymocyte proliferation. Thymus 6: 279-293

44. Sminia T, van Asselt AA, van de Ende MB and Dijkstra CD (1986) Rat thymus macrophages: an immunohistochemical study on fetal, neonatal and adult thymus. Thymus 8: $141-150$

45. Vicente A, Varas A, Moreno J, Sacedon R, Jimenez E and Zapata AG (1995) Ontogeny of rat thymic macrophages. Phenotypic characterization and possible relationships between different cell subsets. Immunology 85: 99-105

46. Fellas NM, Meschan I, Day PL and Douglas CD (1954) Effect of total body Xirradiation on deoxyribonuclease activity of rat spleen. Proc. Soc. Exptl. Biol. Med. 87: 231-233

47. Douglas CD and Day PL (1955) Effect of various doses of total body X-irradiation on total amount of deoxyribonuclease II in rat spleen. Proc. Soc. Exptl. Biol. Med. 89: $616-617$
48. Kowlessar OD, Altman KI and Hempelmann LH (1954) The effect of ionizing irradiation on deoxyribonuclease activities of body fluids. Arch. Biochem. Biophys. 52: 362-372

49. Gordon ER, Gassner E, Okada S and Hempelmann LH (1959) Deoxyribonuclease II activity in lymphoid tissue of rats. Radiation. Res. 10: 505-511

50. Nakayama M, Yagi H, Ishii T, Kayaba S, Gotoh T, Ohtsu S, Ogata M and Itoh T (1997) DNA fragmentation is not the primary event in glucocorticoid-induced thymocytes death in vivo. Eur. J. Immunol. 27: 999-1004

51. Hedgecock EM, Sulston JE and Thomson JN (1983) Mutations affecting programmed cell death in nematde Caenorhabditis elegans. Science 220: $1277-1280$

52. Hevelone J and Hartman PS (1988) An endonuclease from Caenorhabditis elegans: Partial purification and characterization. Biochemical. Genetics. 26: $447-461$

53. Wu Y-C, Stanfield GM and Horvitz HR (2000) Nuc-1, a Caenorhabditis elegans: DNase II homolog, functions in an intermediate step of DNA degradation during apoptosis. Genes. Dev. 14: 536-548

54. Burgoyne LA, Hewish DR and Mobbs J (1974) Mammalian chromatin substructure studies with the calcium-magnesium endonuclease and twodimensional polyacrylamide-gel electrophoresis. Biochem. J. 143: 67-72 